\title{
Controversies in Antenatal Corticosteroid Treatment
}

Prepared for submission to: Prenatal Diagnosis

\section{Thevathasan $\mathrm{I}^{1}$ and Said $\mathrm{JM}^{1,2}$}

1. Maternal Fetal Medicine, Joan Kirner Women's \& Children's Sunshine Hospital, Western Health, St Albans, Australia, 3021

2. Department of Obstetrics and Gynaecology, The University of Melbourne, Parkville, Australia, 3052

Corresponding author: A/Professor Joanne Said Email: jsaid@unimelb.edu.au

\begin{abstract}
Antenatal corticosteroids are now established as one of the cornerstones of therapy in the prevention of neonatal morbidity and mortality prior to preterm birth. Although, this practice is widely accepted, a significant number of controversies exist. This review explores the knowledge gaps regarding the use of antenatal corticosteroids in the preterm, late preterm and term populations. Furthermore, the role of antenatal corticosteroids in special populations, such as diabetes, multiple pregnancies and peri-viable gestations, where high quality data from randomised controlled trials is lacking, is also considered.
\end{abstract}

\section{What is already known about this topic?}

This is the author manuscript accepted for publication and has undergone full peer review but has not been through the copyediting, typesetting, pagination and proofreading process, which may lead to differences between this version and the Version of Record. Please cite this article as doi: $10.1002 / p d .5664$

This article is protected by copyright. All rights reserved. 
- Antenatal corticosteroids are standard of care for preventing morbidity and mortality in preterm birth

\section{What does this study add?}

- Controversies exist regarding dosing, timing and type of antenatal corticosteroids

- Despite antenatal corticosteroids being standard of care, high quality randomised data regarding the use in special populations such as periviable gestations, multiple pregnancy, diabetes and low income settings is lacking.

\section{Introduction}

The role of antenatal corticosteroids in improving the morbidity and mortality of preterm infants has revolutionised perinatal medicine. Since Liggins' and Howie's seminal study of 282 women and their infants, which reported a $16.8 \%$ reduction in respiratory distress syndrome and an $11.8 \%$ reduction in neonatal mortality in preterm infants, consistent findings have been demonstrated. ${ }^{58}$ This has culminated in the latest Cochrane review, confirming the significant reduction in risk of perinatal death, neonatal death, respiratory distress syndrome, intraventricular haemorrhage, necrotizing enterocolitis and, need for mechanical ventilation resulting from a single

This article is protected by copyright. All rights reserved. 
course of antenatal corticosteroids prior to preterm birth. ${ }^{81}$ As a result of many decades of research, this intervention has become a standard part of clinical practice..$^{81}$

Although used almost daily to prevent morbidity and mortality from preterm birth in high income countries throughout the world, a number of controversies and unanswered questions remain regarding this intervention. In the early preterm period, debate persists regarding the optimal dose and timing, choice of corticosteroid and benefits or harms of repeat doses. In the late preterm and term periods, the balance between the short-term benefits and the potential long-term harms continues to be of concern. Furthermore, the lack of robust evidence in special populations, such as women with diabetes, multiple pregnancy and in low resource settings highlights the significant gaps in our knowledge about one of the more common interventions in perinatal medicine.

\section{Pathophysiology and mechanism of action}

The aim of corticosteroid administration prior to preterm birth is to mimic the endogenous increase in corticosteroids that is seen in the late gestational period, which results in the maturation of organs in preparation for postnatal life. Betamethasone and dexamethasone, the two most common corticosteroids administered during pregnancy, are fluorinated synthetic corticosteroids which readily cross the placenta as they are not degraded by placental 11-beta hydroxysteroid

This article is protected by copyright. All rights reserved. 
dehydrogenase 2 (11ß-HSD2). ${ }^{51}$ These glucocorticoids increase surfactant production, increase compliance and maximal lung volume, decrease vascular permeability, mature lung parenchymal structure and increase clearance of lung water to improve respiratory function, and therefore survival. ${ }^{16}$ The extrapulmonary benefits of antenatal corticosteroids, including reductions in intraventricular haemorrhage and necrotizing enterocolitis, are derived both from the beneficial effect on respiratory morbidity as well as the direct effect on the maturation of various tissues. ${ }^{16,19}$ Indeed, laboratory studies have identified over 300 specific nuclear target genes which are regulated by betamethasone. ${ }^{27}$

\section{Controversies in the preterm period}

The use of antenatal corticosteroids to prevent morbidity and mortality prior to 34 - 35 weeks gestation is now well established as an evidence based recommendation by guidelines around the world with subtle differences as demonstrated in Table 1.11, 2, 72, 95 The latest Cochrane Review, published in 2017, included 7774 women and 8158 infants, reported significant reductions in neonatal death (RR 0.69, 95\% Cl 0.59-0.81), respiratory distress syndrome $(\mathrm{RR} \quad 0.66,95 \% \mathrm{Cl} \quad 0.56-0.77)$, and necrotizing enterocolitis (RR $0.50,95 \% \mathrm{Cl}$ 0.32-0.78) ${ }^{81}$ Neonates exposed to antenatal corticosteroids were also less likely to require neonatal respiratory support (RR 0.68 , $95 \% \mathrm{Cl} 0.56-0.84)$, surfactant therapy (RR $0.68,95 \% \mathrm{Cl} 0.51-0.90)$ and oxygen supplementation (Mean Duration (MD) -2.68 days, $95 \% \mathrm{Cl}-5.51$ to -0.21 days). ${ }^{81}$ Long

This article is protected by copyright. All rights reserved. 
term outcomes are less certain, in part due to the small number of follow up studies. Nevertheless, no significant increases, and a non-statistically significant reduction in developmental delay (RR 0.48, 95\% Cl 0.24-1.00) and cerebral palsy (RR 0.64, 95\% $\mathrm{Cl}$ 0.35-1.03) was observed in children at 2 years of age, although it is important to note that fewer than 1000 children were included in follow up studies contributing to this component of the meta-analysis. ${ }^{81}$

Controversies still remain during the preterm period, including the choice of corticosteroid, dose of corticosteroid, timing of corticosteroids and the use of repeat doses.

\subsection{Choice of corticosteroid}

Betamethasone and dexamethasone are fluorinated corticosteroids and are the most commonly prescribed corticosteroids for the prevention of morbidity and mortality associated with preterm birth. International guidelines recommend either the use of betamethasone or dexamethasone intramuscularly as the antenatal corticosteroid of choice when preterm birth is imminent. ${ }^{11,72,95,39,109,2}$

Animal studies comparing the two corticosteroids favour betamethasone as the superior agent. A rat study comparing the effects of betamethasone, dexamethasone and prednisolone reported that betamethasone was more potent at inducing surfactant

This article is protected by copyright. All rights reserved. 
production compared to the other two types of steroids. ${ }^{10} \mathrm{~A}$ small trial comparing the impact of antenatal administration of betamethasone or dexamethasone and placebo upon neurobehavioural development of mice offspring demonstrated that dexamethasone induced a brief period of developmental delay, separation anxiety and reduction in memory process with the study concluding that betamethasone may be the preferred corticosteroid when preterm birth is imminent. ${ }^{80}$

Human studies have not validated these findings. A study of 82 women with 97 fetuses with preterm labour were randomly allocated to receive either betamethasone or dexamethasone for fetal lung maturation. Cardiotocogram (CTG) recordings were obtained before administration of the first dose, at 24-48 hours and 4-7 days after administration. Women who were on other medications that may impact upon CTG variability, such as anti-hypertensives, were excluded from the study. There were no differences in the incidence of neonatal respiratory distress syndrome, however a statistically significant decrease in fetal heart rate variability was seen with betamethasone use that was not present in the dexamethasone group at 24-48 hours. ${ }^{91}$ These observed changes had returned to normal by 4-7 days. ${ }^{91}$ In contrast, reduction in short term and long term variability was observed for both dexamethasone and betamethasone in another randomised trial of 105 women, which returned to baseline by day $4 .{ }^{99}$

This article is protected by copyright. All rights reserved. 
The most recent Cochrane review of ten trials which included 1159 women and 1213 infants, reported no significant differences in the rates of neonatal death (RR 1.41, 95\% Cl $0.54-3.67$ ) or respiratory distress syndrome when different types of corticosteroid were used $(\mathrm{RR} 1.06,95 \% \mathrm{Cl} 0.88$ - 1.27), however there was a significantly decreased rate of intraventricular haemorrhage in the dexamethasone group compared with betamethasone ( $\mathrm{RR} 0.44,95 \% \mathrm{Cl} 0.21-0.92) .{ }^{22}$ There were no significant differences in maternal outcomes or childhood outcomes at 18 months of age. $^{22}$ This review concluded that high quality trials were needed to establish which drug was most effective and caused the least harm. A large Australasian trial, comparing Betamethasone and Dexamethasone on the impact on survival rates free of childhood neurosensory disability has completed recruitment and will provide valuable data regarding the optimal corticosteroid. ${ }^{30}$

\subsection{Dose}

The recommended total dose for dexamethasone or betamethasone in anticipated preterm birth is $24 \mathrm{mg}$ intramuscularly. Betamethasone is usually given as two doses of $12 \mathrm{mg}$ administered 24 hours apart, while dexamethasone is given as four doses of $6 \mathrm{mg}$ administered every 12 hours. ${ }^{11,} 39$ Dexamethasone has an advantage in that it can be given intravenously in cases when intramuscular injections are contraindicated (for example severe thrombocytopaenia in HELLP syndrome or when therapeutic

This article is protected by copyright. All rights reserved. 
anticoagulation is required) although there are limited data available regarding the pharmacokinetics of intravenous dosing ${ }^{16}$ which theoretically may expose the fetus to higher peak levels of Dexamethasone than the intramuscular route. ${ }^{16}$

The dose used in the original Liggins study was extrapolated from sheep studies and combined $6 \mathrm{mg}$ of betamethasone phosphate with $6 \mathrm{mg}$ betamethasone acetate in two doses 24 hours apart. ${ }^{58}$ This regimen allows rapid exposure to betamethasone from the phosphate form and more sustained exposure from the acetate form. ${ }^{58,16}$ Pharmacokinetic studies demonstrate that, with this dosing, more than $75 \%$ of glucocorticoid receptors in fetal tissue are occupied. ${ }^{15}$ Dexamethasone has similar pharmacokinetics, although a lower peak level but a longer duration of elevated activity. ${ }^{16} \mathrm{~A}$ follow up study by Howie and Liggins which compared a double dose regimen to the original dosing regimen, did not demonstrate any increased neonatal benefit, presumably because the original dosing regimen achieves maximal glucocorticoid receptor activation..$^{45}$

Recent sheep studies have demonstrated that lower doses of betamethasone appear to be equally efficacious in inducing fetal lung maturation, with administration of a single dose resulting in similar benefits to the administration of two doses, 24 hours apart, currently used in practice..$^{47,89}$ No trials investigating dosing regimens were available for inclusion in the most recent Cochrane meta-analysis on the subject, but a multicenter randomised double blind placebo-controlled non-inferiority trial in 37 
tertiary French centres, aims to compare two doses of betamethasone compared with a single dose on the outcome of respiratory distress syndrome and has commenced recruiting..$^{90}$ Optimal dosing of antenatal corticosteroids should adhere to the principal of achieving the desired effect at the lowest possible fetal exposure. ${ }^{52}$

\subsection{Timing and interval}

There have been very few studies investigating the optimal dose interval and timing of antenatal corticosteroids. The commonest regimen in use, administration of two doses of Betamethasone 24 hours apart, is derived from the original study reported by Liggins and Howie. ${ }^{58}$ There were no pharmacokinetic studies investigating the optimal dose and interval to achieve the desired beneficial effects whilst minimizing any short or long-term off-target effects. ${ }^{52}$ A small retrospective cohort study compared a 12hourly dosing regimen of Betamethasone with a 24-hourly regimen in 166 women who delivered less than 48 hours from commencement of antenatal corticosteroid therapy and demonstrated no significant differences in the rates of respiratory distress syndrome, necrotizing enterocolitis, intraventricular haemorrhage, requirement for respiratory support, length of neonatal intensive care unit stay or neonatal death. ${ }^{43} \mathrm{~A}$ randomised controlled trial which included 228 women and 260 fetuses reported that whilst 12 hour dosing of Betamethasone compared with 24 hour dosing had no impact on the incidence of respiratory distress syndrome (36.5\% vs $37.3 \%, p=0.91)$, there was a statistically significant higher incidence of necrotizing enterocolitis in the group

This article is protected by copyright. All rights reserved. 
who received 12 hourly administration $(6.2 \%$ versus $0.0 \%, p=0.03) .{ }^{55}$ Although these results should be interpreted with caution due to the small numbers, the pharmacokinetics of betamethasone suggest that more frequent dosing intervals may result in higher peak levels of betamethasone in the fetal circulation. It is plausible that this may contribute to adverse outcomes due to saturation of placental and fetal glucocorticoid receptors. ${ }^{16}$

International guidelines broadly agree that administration of antenatal corticosteroids should be within 7 days prior to preterm birth, ${ }^{11,72,39,95,2}$ however, data regarding the optimal interval between administration and birth are limited. Recent cohort data from the Effective Perinatal Intensive Care in Europe demonstrated that infant mortality was reduced significantly even when antenatal corticosteroids were administered only a few hours prior to birth with maximal reductions achieved at 18 to 24 hours following administration. ${ }^{74}$ These data challenge the view that the optimal window for administration is at least 24 hours prior to birth.

\subsection{Repeat doses}

Perhaps the most contentious issue related to antenatal corticosteroids in the preterm period is that of repeat doses when preterm delivery does not occur as predicted after corticosteroid administration. Currently available bedside tests to predict the risk of

This article is protected by copyright. All rights reserved. 
preterm birth have a high negative predictive value but low positive predictive value. ${ }^{79}$ This has resulted in a tendency to administer antenatal corticosteroids when the risk of preterm birth is thought to be high, even though retrospective studies have shown that only about $33 \%$ of women who receive antenatal corticosteroids birth prior to $34^{+0}$ weeks gestation. ${ }^{87}$ Furthermore, even when preterm birth was indicated only $48 \%$ of women at a University Hospital in USA received antenatal corticosteroids within the optimal period of 7 days prior to birth. ${ }^{5}$

The Australasian Collaborative Trial of Repeat Doses of Steroids (ACTORDS) investigated 982 women who remained at risk of preterm birth prior to $32^{+0}$ weeks gestation, more than 7 days after receiving the first course of antenatal corticosteroids. This double blind, placebo controlled trial, randomised women to weekly administration of betamethasone $11.4 \mathrm{mg}$ or saline placebo. ${ }^{31}$ There was a statistically significant decrease in respiratory distress syndrome (adjusted Relative Risk (RR) $0.82,95 \% \mathrm{Cl} 0.71-0.95$ ), use of oxygen therapy (adjusted RR $0.90,95 \% \mathrm{Cl} 0.81-0.99$ ) and duration of mechanical ventilation in the treatment group; however, $36 \%$ of women exposed to repeat doses of antenatal corticosteroids gave birth after 34 weeks gestation. ${ }^{31}$ Although z-scores for head circumference and weight at the time of birth were significantly lower in those exposed to corticosteroids, there were no differences seen in anthropometric measurements or z-scores at hospital discharge. ${ }^{31}$ In contrast, the National Institute of Child Health and Human Development (NICHD) study investigating the safety and efficacy of repeat doses of antenatal corticosteroids was 
prematurely terminated due to a statistically significant increase in the rate of neonates with birthweight below the 10th percentile in the group exposed to repeat steroids, with concerns raised about a potential dose response effect with infants exposed to a greater number of courses having a greater risk of low birthweight. ${ }^{107}$ However, in the interim analysis of the 495 patients, whilst there was no difference in the primary composite neonatal outcome (RR $0.61,95 \% \mathrm{Cl} 0.34-1.08)$ there was a significant reduction in the requirement for ventilator support $(\mathrm{RR} 0.62,95 \% \mathrm{Cl} 0.46-0.85)$, surfactant therapy $(\mathrm{RR} 0.60,95 \% \mathrm{Cl}$ 0.41-0.88) and rates of bronchopulmonary dysplasia (RR 0.45, 95\% Cl 0.26-0.79). ${ }^{107}$

The Multiple courses of Antenatal Corticosteroids for preterm birth (MACS) trial investigated the effect of multiple courses of antenatal corticosteroids, but in contrast to previous trials, used a longer interval between repeat does of 14 days instead of 7 days. $^{70}$ The trial recruited 1858 women at risk of preterm birth who remained undelivered 14-21 days after an initial course of antenatal corticosteroids. Women were randomised to receive betamethasone $12 \mathrm{mg}$ or saline placebo every 14 days. There was no difference in the composite primary outcome of neonatal morbidity or mortality (mean difference $1.04,95 \% \mathrm{Cl} 0.77-1.39$ ) or respiratory distress syndrome (mean difference 1.14, 95\% $\mathrm{Cl}$ 0.80-1.58). However, there were significant reductions in birthweight, length at birth and mean head circumference. ${ }^{70}$ The Cochrane review which included 4733 women and 5700 babies from 10 trials, showed a significant improvement in respiratory distress syndrome ( $\mathrm{RR} 0.83,95 \% \mathrm{Cl} 0.75-0.91)$ and 
serious infant outcome ( $\mathrm{RR} 0.84,95 \% \mathrm{Cl} 0.75-0.94)$ but a significant decrease in mean birth weight which was no longer significant when adjusted for gestational age. ${ }^{32} \mathrm{~A}$ recent individual participant meta-analysis which included eleven randomised trials involving 4,857 women and 5,915 infants reported a significant decrease in the use of respiratory support $(\mathrm{RR} 0.91,95 \% \mathrm{Cl} 0.85-0.97)$ but also a significant decrease in birthweight in the group exposed to repeat prenatal steroids (mean difference -0.12 , $95 \% \mathrm{Cl}-0.18$ to -0.06$).{ }^{33}$ No differences were seen in composite serious outcome for child or woman. ${ }^{33}$

Reports regarding the long-term outcomes following exposure to repeat doses of steroids are conflicting. Concerns were raised in the two year follow up of the ACTORDS trial, as children exposed to repeat doses of corticosteroids were more likely to require assessment for attention disorders (adjusted RR 1.87, 95\% Cl 1.033.42). ${ }^{28}$ No differences were seen in the rate of survival free of major disability, body size, blood pressure, respiratory morbidity or use of health services. ${ }^{28}$ Six to eight year follow up of the ACTORDS trial was largely reassuring with no differences seen in cardiometabolic outcomes, ${ }^{24,62}$ function residual lung capacity, ${ }^{60}$ hypothalamuspituitary adrenal suppression ${ }^{17}$ or bone mass ${ }^{64}$ however, it should be noted that these follow up studies were largely restricted to subsets of the ACTORDS cohort.

Five year follow up of the MACS study, showed that those exposed to multiple doses of antenatal corticosteroids but then birthed beyond 37 weeks were at significant 
increased risk of a composite primary outcome of death or survival with neurodevelopmental disability (OR 1.69, 95\% Cl 1.04-2.77) and neurosensory disability (OR 3.70, 95\% Cl 1.57-8.75). ${ }^{12}$ Furthermore, follow up of the NICHD study identified an increase in the rate of cerebral palsy in neonates exposed to multiple doses of antenatal corticosteroids with 6 children (2.9\%) in the repeat corticosteroid group being diagnosed with cerebral palsy and 1 child in the placebo group (0.5\%), RR 5.7, 95\% $\mathrm{Cl} 0.7-46.7, \mathrm{p}=0.12) .{ }^{106}$ Although not statistically significant, a direct neurological effect of corticosteroids on the developing fetal brain is plausible. ${ }^{110}$ It was also notable that 5 of the 6 children in the repeat corticosteroids group were born after 34 weeks and that all six of these children had been exposed to either 4 or 5 courses of antenatal corticosteroids, raising the possibility of a dosage effect. ${ }^{106}$

Undoubtedly, repeat courses of antenatal corticosteroids improve short term respiratory outcomes in neonates, however no differences are seen in long term outcomes and potential harm has been observed in children that were exposed to multiple courses of antenatal corticosteroids who are born after 34 weeks. For women who remain at risk of preterm birth beyond the optimal treatment period after an initial course of antenatal corticosteroids, international guidance varies, with most guidelines only recommending one further single course of $24 \mathrm{mg}$ Betamethasone in divided doses or up to a maximum of 2 further single injections of $12 \mathrm{mg}$ Betamethasone for women who remain at risk of preterm birth prior to $32^{+6}$ weeks ${ }^{11}$ or $34^{+0}$ weeks ${ }^{2}$ (Table 1). ${ }^{11,2,95,72}$ The limited data regarding long term follow up of infants exposed to repeat 
doses of antenatal corticosteroids support a conservative approach of adhering to the principle of minimising exposure.

\section{Controversies in the late preterm and early term period}

\subsection{Late preterm administration}

The majority of preterm births occur in the late preterm period between $34^{+0}$ and $36^{+6}$ weeks' gestation, and whilst mortality rates at the late preterm period and early term period are similar, morbidity and medical intervention rates are significantly higher in the late preterm compared to the early term period. ${ }^{14}$, ${ }^{21}$ Prior to the publication of the Antenatal Betamethasone in Late Preterm (ALPS) trial, the use of antenatal corticosteroids beyond $34^{+0}$ weeks gestation was inconsistent with little international consensus. ${ }^{46}$

The ALPS trial was a multicenter, double blind, randomised trial which included 2831 women at high risk of birth during the late preterm period. Women were randomised to receive either two doses of betamethasone $11.4 \mathrm{mg}$ or saline placebo. The primary outcome was a composite measure of respiratory morbidity, stillbirth and neonatal mortality within 72 hours of birth. ${ }^{42}$ There was a significantly decreased rate of the primary outcome in the group that received betamethasone $(\mathrm{RR} 0.80,95 \% \mathrm{Cl} 0.66$ 0.97, $p=0.02$ ), and composite severe respiratory morbidity ( $R R \quad 0.67,95 \% \mathrm{Cl} 0.53-$

This article is protected by copyright. All rights reserved. 
$0.84, p<0.001) .{ }^{42}$ There was a significantly lower rate of transient tachypnoea of the newborn (a relatively self-limiting condition) $(\mathrm{RR} 0.68,95 \% \mathrm{Cl} 0.53-0.87, \mathrm{p}=0.002)$, in those exposed to antenatal corticosteroids but no difference in the rate of respiratory distress syndrome (RR 0.87, 95\% Cl $0.65-1.17, p=0.36)$. Somewhat unexpectedly, there was a significantly increased rate of neonatal hypoglycaemia $(\mathrm{RR} 1.60,95 \% \mathrm{Cl}$ 1.37-1.87, $p<0.001)$ in those exposed to betamethasone antenatally. ${ }^{42}$ A subsequent meta-analysis which included 5698 singleton pregnancies at late preterm or term gestations (including those recruited to the ALPS study), showed a significantly lower rate of severe respiratory distress syndrome (RR $0.55,95 \% \mathrm{Cl} 0.33-0.91)$ and transient tachypnoea of the newborn ( $\mathrm{RR} 0.56,95 \% \mathrm{Cl} 0.37-0.86)$ with significantly higher rates of neonatal hypoglycaemia ( $R R$ 1.61, 95\% Cl 1.38 to 1.87 ) in those exposed to antenatal corticosteroids. ${ }^{86}$

These findings have been enthusiastically embraced by the American College of Obstetricians and Gynecologists, which now recommends a single course of corticosteroids for women at risk of delivery in the late preterm period between $34^{+0}$ and $36^{+6}$ weeks if they have not previously received a course of antenatal corticosteroids. $^{2}$ However, it is pertinent to note that the relative risk of neonatal hypoglycaemia was higher than the respiratory benefit gained from the use of antenatal corticosteroids during the late preterm and term period, although the severity and impact of the hypoglycaemia was not clarified. ${ }^{42}$ Hypoglycaemia in the neonatal period has been associated with neurodevelopmental delay, cerebral palsy, 
neuropsychiatric defects, lower intelligence quotient, poor executive function and smaller head circumference, depending upon the severity and duration of the hypoglycaemia. ${ }^{92,53,63}$ Furthermore, there have been concerns raised regarding the lack of robust long term follow up of infants exposed to antenatal corticosteroids in the late preterm period for a modest benefit in respiratory morbidity, which is mostly due to the self-limiting condition of transient tachypnoea of the newborn. ${ }^{29,49,50,40}$

\subsection{Early term administration}

Internationally, there is an increasing trend towards indicated birth due to labour induction or caesarean section in the early term period between $37^{+0}-39^{+0}$ weeks' gestation. ${ }^{68}$ Due to the significantly increased respiratory morbidity associated with birth prior to 39 weeks of gestation ${ }^{111}$, the American College of Obstetricians and Gynecologists recommends against non-medically indicated delivery prior to 39 weeks. ${ }^{3}$ Despite these recommendations approximately $40 \%$ of all non-emergency caesarean deliveries are performed prior to $39^{+0}$ weeks gestation. ${ }^{100}$ Furthermore, there may be maternal or fetal indications for delivery by caesarean section prior to this gestation. ${ }^{104,26,38}$ Due to the significantly increased risk of respiratory morbidity for fetuses born via caesarean section prior to labour onset during the early term period (as demonstrated in Figure 1) ${ }^{100,44}$ antenatal corticosteroids have been proposed as a way of reducing adverse neonatal outcomes. ${ }^{86}$

This article is protected by copyright. All rights reserved. 
The Antenatal Steroids for Term Caesarean Section (ASTECS) trial recruited 998 women in a pragmatic, open label, randomised trial comparing two doses of betamethasone in the 48 hours prior to caesarean birth with usual treatment. ${ }^{97}$ The majority of women (55.2\%) gave birth prior to 39 weeks' gestation. There was a significant decrease in special care nursery admissions due to respiratory distress in the group that received corticosteroids prior to 39 weeks (RR $0.46,95 \% \mathrm{Cl} 0.23-0.93$, $p=0.021$ ). It is noteworthy that the majority of cases of respiratory distress were due to transient tachypnoea of newborn $(2.1 \%$ in the Betamethasone group compared to $4.0 \%$ in the control group) while the overall rate of respiratory distress syndrome at term gestations was low ( $0.2 \%$ in the Betamethasone group compared to $1.1 \%$ in the control group). ${ }^{97}$ No details were provided regarding the rates of neonatal hypoglycaemia, however, it is worth noting that the rate of admission to the special care baby unit for non-respiratory related conditions was higher in the betamethasone group (3.2\% compared to the control group 1.7\%). ${ }^{97}$ Two further randomised trials from Egypt comparing dexamethasone administration prior to caesarean section prior to labour onset confirmed the significant reduction in neonatal nursery admission secondary to respiratory morbidity, largely due to a reduction in transient tachypnea of the newborn rather than respiratory distress syndrome. ${ }^{6,71}$ However, it is relevant to note the unusually high rates of respiratory morbidity in the placebo group in the trial reported by Ahmed et al, with approximately $23 \%$ having respiratory morbidity despite being born in the early term period. ${ }^{6}$ In contrast, a non-blinded randomised trial comparing three doses $8 \mathrm{mg}$ of intramuscular dexamethasone administered prior 
to elective caesarean section beyond 38 weeks gestation to standard care, did not find any statistically significant respiratory benefit in the treatment group. ${ }^{73}$

Long term follow up from these studies is only available from the ASTECS trial, ${ }^{97}$ at 815 years via information ascertained from parent reported questionnaire and school reports of national standard assessment tests. ${ }^{98}$ Less than half of the participants in the original trial were involved in the follow up, which demonstrated no differences in a range of self-reported health outcomes in children exposed to betamethasone antenatally. School reports were available for just over a third of participants (37\%) and analysis of academic ability based on these school reports demonstrated that children who were exposed to betamethasone antenatally were significantly more likely to be in the lower quartile of academic ability (17.7\% vs. $8.5 \%, p=0.03) .{ }^{98}$ These findings should be interpreted with caution due to the unblinded nature of the trial and the inherent bias that is present with low follow up rates and reliance on parental recall, however these findings do raise concerns regarding the long term safety of antenatal corticosteroids and the potential for adverse neurocognitive outcomes which may be biologically plausible due to potential increased rates of neonatal hypoglycaemia (a finding which was not investigated) or a possible direct effect of corticosteroids on the fetal brain. ${ }^{110}$ Betamethasone and dexamethasone cross the placenta rapidly as they are poorly inactivated by placental $11 ß-H S D 2 .{ }^{110}$ This enzyme is also highly expressed in the fetal brain (as opposed to the adult brain) and plays an important role in limiting the exposure of the fetal brain to endogenous and exogenous 
corticosteroids. $^{110}$ The fetal brain is therefore susceptible to the high levels of Betamethasone following antenatal corticosteroid administration. Corticosteroids are known to initiate terminal maturation, axonal remodelling and contribute to programmed cell death. ${ }^{110}$ The risk of neurocognitive morbidity is higher in early preterm infants compared to the late preterm or term infants (Figure 2). ${ }^{54,88}$ Therefore, the impact of antenatal corticosteroids on subtle neurocognitive function may be more apparent and significant in the late preterm/term group.

Animal studies investigating late term exposure to antenatal corticosteroids have raised concerns regarding long term outcomes. Rat studies have shown that offspring that were exposed to dexamethasone were more likely to have reduction in glomeruli, develop hypertension and have an increased risk of insulin resistance with these effects being pronounced when dexamethasone exposure was in later gestation. ${ }^{76,75}$ In a small study of rhesus monkeys, those that were treated with dexamethasone in pregnancy were shown to have a $30 \%$ reduction in size and segmental volumes of the hippocampus compared to monkeys treated with placebo. ${ }^{101}$

A study of the cord blood of 76 singleton newborns, on average 37-38 weeks' gestation, compared venous cord blood hormonal and metabolic markers of those exposed to betamethasone compared to controls prior to elective caesarean section. ${ }^{94}$ Statistically significant increases were seen in cortisol, c-peptide, insulin-like growth factor and glucose levels in those exposed to corticosteroids. ${ }^{94}$ These findings suggest

This article is protected by copyright. All rights reserved. 
that fetuses exposed to antenatal betamethasone are born hyperinsulinemic and are therefore at higher risk of neonatal hypoglycaemia and its subsequent consequences. ${ }^{13}$ A case-control study of 209 children born at term (mean 39.3 weeks gestation) who were either exposed to antenatal corticosteroids or not, reported significantly higher cortisol secretion in response to standardized psychosocial stress testing at the age of $6-11$ in those exposed to antenatal corticosteroids. ${ }^{7}$ Follow up after 30 years of the original Auckland based trial undertaken by Liggins and Howie, in which approximately $30 \%$ of fetuses exposed to steroids delivered at term, demonstrated increase in insulin resistance but no other difference in cardiovascular outcomes, although it is important to note that the peak incidence of cardiovascular morbidity occurs well after 30 years of age. ${ }^{35}$ Long term follow-up of adults who were exposed to antenatal corticosteroids at term is limited, although the evidence we have thus far raises enough concern to justify the need for long term follow up studies.

\section{Antenatal Corticosteroids in Special Populations}

The use of antenatal corticosteroids is being extrapolated beyond populations for which robust randomised controlled data exists.

\subsection{Periviable gestation}

This article is protected by copyright. All rights reserved. 
Survival rates in infants born between $22^{+0}-24^{+0}$ weeks' gestation varies, with decreasing survival rates as gestation decreases. ${ }^{77}$ Variable practice exists in this population when women are at risk of preterm delivery. ${ }^{85}$ Retrospective analysis of infants born between $22^{+0}-23^{+0}$ weeks of gestation revealed that antenatal corticosteroids were associated with a significant reduction in death prior to hospital discharge of preterm infants born between $22^{+0}-23^{+0}$ weeks of gestation (adjusted hazard ratio $0.72,95 \% \mathrm{Cl} 0.53-0.97)$, however no significant differences were seen in neonatal morbidity between the corticosteroid exposed and unexposed infants during this gestational period. ${ }^{67}$ A large cohort study of 10,541 neonates born at 22 to 25 weeks gestation revealed no significant benefit of antenatal corticosteroids on neonatal morbidity or mortality between 22 to 23 weeks gestation, but a significant improvement in mortality and composite outcomes of respiratory, intracranial and gastrointestinal morbidity between 23 to 24 weeks gestation. ${ }^{23}$ There are no randomised controlled trial data in this population and no studies investigating the long-term outcomes of antenatal corticosteroids in this population. The lack of randomised controlled trial data has led to significant discordance between use of antenatal corticosteroids and resuscitation at these early gestations, with a recent retrospective study demonstrating that $23.3 \%$ of live births at 23 weeks of gestation were resuscitated but not exposed to antenatal corticosteroids. ${ }^{84}$ As recommended by a number of international guidelines, multidisciplinary counselling and collaborative decision-making regarding resuscitation is imperative to guide the rational use of corticosteroids, taking into account the parent's wishes and expectations as well as 
the availability and expertise of neonatal intensive care (Table 1). ${ }^{11,2,} 72,95$ Improvements in neonatal care at periviable gestations will likely result in a progressive reduction in the gestational age at which antenatal corticosteroids should be offered.

\subsection{Multiple pregnancy}

A number of published randomised trials investigating the role of antenatal corticosteroids included a proportion of women with multiple pregnancies. ${ }^{81,} 11$ Prediction of preterm labour and therefore optimal timing of antenatal corticosteroids is less consistent in twin pregnancies compared to singletons. ${ }^{83}$ Available evidence regarding the utility of antenatal corticosteroids in this population varies since women with multiple pregnancies are frequently excluded from randomised trials investigating antenatal corticosteroids.

Retrospective analysis of data from a trial investigating the use of intramuscular progesterone for the prevention of preterm birth in twin pregnancies, in which $35 \%$ of neonates were exposed to antenatal corticosteroids did not demonstrate significant improvements in respiratory distress syndrome (RR 1.28, 95\% Cl 0.97-1.71). ${ }^{103}$ In fact, exposure to antenatal corticosteroids was associated with a significant increased need for neonatal intensive care admission (adjusted RR 1.22, 95\% Cl 1.09-1.36) and mechanical ventilation (adjusted RR 1.52, 95\% CI 1.12-2.09). ${ }^{103}$

This article is protected by copyright. All rights reserved. 
In contrast, a Canadian retrospective study investigating 2516 twin neonates, approximately $70 \%$ of whom received antenatal corticosteroids between 1-7 days before birth showed significant reductions in neonatal mortality, need for mechanical ventilation and severe neurological injury. ${ }^{65}$ The importance of optimal timing of antenatal corticosteroids in twin populations was demonstrated by a retrospective study which showed significant reduction in the incidence of respiratory distress when antenatal corticosteroid delivery was between 2-7 days but not beyond this interval. ${ }^{56}$ The increased risk of respiratory distress in twin pregnancies is thought to be multifactorial and includes lower gestational age at delivery, increased risk of caesarean delivery as well as genetic factors. ${ }^{93}$ A cohort study investigating the utility of multiple courses of antenatal corticosteroids in twin pregnancies, found that whilst respiratory distress syndrome was increased in twin pregnancies, no reduction was seen with either single or multiple course of antenatal corticosteroids. ${ }^{25}$ No randomised trials have been published in higher order multiple pregnancies, however a small retrospective cohort study reported no significant differences in surfactant use, birthweight or head circumference in triplets exposed to antenatal corticosteroids compared to those who were not exposed. ${ }^{34}$ There were also no adverse neurodevelopmental outcomes at 1 year of age in those exposed to anteatnal corticosteroids. ${ }^{34}$ International guidelines recommend administering antenatal corticosteroids, similar to that of a singleton pregnancy in this population, whilst acknowledging the limitations of the published data. ${ }^{11,39}$

This article is protected by copyright. All rights reserved. 


\subsection{Diabetes}

Diabetes, both gestational and pre-gestational, is the most common medical condition experienced in pregnancy and the rates of both gestational diabetes and Type 2 diabetes are increasing. ${ }^{69,59}$ Maternal diabetes increases the risk of caesarean section and earlier delivery. ${ }^{102}$ Interestingly, the majority of studies examining the impact of antenatal corticosteroids on neonatal outcome have excluded women with diabetes or have had an extremely small population of women with diabetes from which the impact of antenatal corticosteroids on neonatal outcomes cannot be extrapolated. ${ }^{6,71,97,9,42}$ This is despite the well-known risks of pre-gestational diabetes on obstetric outcomes including higher rates of preterm and early term cesarean sections and increased risks of neonatal respiratory distress syndrome. ${ }^{4,} 18$ Furthermore, the risk of maternal hyperglycemia after exposure to antenatal corticosteroids is well established. ${ }^{57,48}$ Pregnant women with pre-existing diabetes are at a higher risk of diabetic ketoacidosis, with diabetic ketoacidosis occurring at lower blood glucose levels compared with the non-pregnant population ${ }^{36,41}$, and therefore the administration of antenatal corticosteroids may increase the risk of diabetic ketoacidosis. Maternal hyperglycemia can also lead to fetal hyperinsulinemia and therefore neonatal hypoglycemia and subsequent short, and long-term effects. Moreover, maternal hyperglycaemia and subsequent fetal hyperinsulinaemia is associated with delayed maturation of the surfactant producing Type II alveolar cells ${ }^{78,66,61}$ as well as fetal

This article is protected by copyright. All rights reserved. 
myocardial hypertrophy. ${ }^{37}$ Myocardial hypertrophy can contribute to left ventricular outflow obstruction, poor cardiac output and congestive cardiac failure after birth; a combination that also contributes to neonatal respiratory distress. ${ }^{37}$ Thus, it is plausible that antenatal corticosteroids may exacerbate the fetal hyperinsulinaemia and subsequent respiratory distress in neonates born to women with diabetes, as well as increasing the risk of adverse events related to neonatal hypoglycaemia.

\subsection{Low resource settings}

Although the burden of preterm birth is highest in low income countries, these settings face a number of unique challenges including inaccuracy with gestational age estimation, difficulties in predicting preterm birth and the limited availability and access to resources required to support high quality evidence based care. ${ }^{108,82,96}$ Despite the evidence regarding the benefits of antenatal corticosteroids in preventing morbidity and mortality following preterm birth, only a minority of women in low resource countries receive antenatal corticosteroids. ${ }^{20}$ The Antenatal Corticosteroids Trial (ACT), was a cluster-randomised trial in six rural and semi-urban low resource countries, which investigated the role of antenatal corticosteroids in addition to standard care, compared to standard care alone. The study was predominantly aiming to improve outcomes for small for gestational age babies. ${ }^{8}$ Although there was a significant increase in the use of antenatal corticosteroids, no differences in neonatal mortality were seen in the small for gestational age group. Conversely, in the overall

This article is protected by copyright. All rights reserved. 
population, those exposed to antenatal corticosteroids had a significantly higher rate of neonatal mortality (RR 1.12, 95\% $\mathrm{Cl} 1.02-1.22)$ and suspected maternal infection (OR 1.45, 95\% Cl 1.33-1.5). ${ }^{8}$ The authors hypothesize the increased neonatal mortality may be due to poor prediction of gestational age. Consequently, the World Health Organisation only recommends antenatal corticosteroids in low income settings when gestational age is accurate, preterm birth considered imminent, in the absence of maternal infection and adequate obstetric and neonatal care are available. ${ }^{1}$ Given these concerns, there is an urgent need to assess the efficacy and harms of antenatal corticosteroids in this setting. ${ }^{105}$

\section{Conclusion}

A number of issues remain unresolved and controversies exist regarding the use of antenatal corticosteroids. Urgent high quality, reproducible studies with long term follow-up are required to establish the optimal dose and type of corticosteroid, the benefits and harms of repeated doses, and the role of corticosteroids in the late preterm and early term periods. The inclusion of neonatal hyperglycaemia as an outcome of interest in future trials will help to establish an understanding of the importance of this potentially significant adverse short-term outcome. It is imperative to study special populations that have traditionally been excluded from trials of antenatal corticosteroids rather than simply rely on extrapolation from homogenous population based studies. Given the emerging concerns relating to longer term

This article is protected by copyright. All rights reserved. 
adverse outcomes in older children and adults who were exposed to corticosteroids antenatally, longitudinal follow up studies are imperative. The implementation of antenatal corticosteroids in low income countries, where the burden of disease is the highest, requires particular attention. Perhaps the only facet of antenatal corticosteroids that we can have complete consensus on, is that a single course of antenatal corticosteroids when administered to a singleton pregnancy in a high income country between $24^{+0}-34^{+6}$ weeks gestation, that subsequently delivers within seven days of administration, reduces the risk of neonatal death and improves neonatal outcome.

This article is protected by copyright. All rights reserved. 


\section{References}

1 WHO Guidelines Approved by the Guidelines Review Committee. In WHO Recommendations on Interventions to Improve Preterm Birth Outcomes. World Health Organization Copyright (c) World Health Organization 2015.: Geneva, 2015;

2 Committee Opinion No. 713: Antenatal Corticosteroid Therapy for Fetal Maturation. Obstet Gynecol, 2017; 130: e102-e109.

3 ACOG Committee Opinion No. 765 Summary: Avoidance of Nonmedically Indicated Early-Term Deliveries and Associated Neonatal Morbidities. Obstet Gynecol, 2019; 133: 404405.

4 ABELL, SK, BOYLE, JA, DE COURTEN, B, et al. Contemporary type 1 diabetes pregnancy outcomes: impact of obesity and glycaemic control. Med J Aust, 2016; 205: 1627.

5 ADAMS, TM, KINZLER, WL, CHAVEZ, MR, et al. The timing of administration of antenatal corticosteroids in women with indicated preterm birth. Am J Obstet Gynecol, 2015; 212: 645.e1-4.

6 AHMED, MR, SAYED AHMED, WA \& MOHAMMED, TY. Antenatal steroids at 37 weeks, does it reduce neonatal respiratory morbidity? A randomized trial. J Matern Fetal Neonatal Med, 2015; 28: 1486-90.

7 ALEXANDER, N, ROSENLOCHER, F, STALDER, T, et al. Impact of antenatal synthetic glucocorticoid exposure on endocrine stress reactivity in term-born children. J Clin Endocrinol Metab, 2012; 97: 3538-44.

8 ALTHABE, F, BELIZAN, JM, MCCLURE, EM, et al. A population-based, multifaceted strategy to implement antenatal corticosteroid treatment versus standard care for the reduction of neonatal mortality due to preterm birth in low-income and middle-income countries: the ACT cluster-randomised trial. Lancet, 2015; 385: 629-639.

9 AMIYA, RM, MLUNDE, LB, OTA, E, et al. Antenatal Corticosteroids for Reducing Adverse Maternal and Child Outcomes in Special Populations of Women at Risk of Imminent Preterm Birth: A Systematic Review and Meta-Analysis. PLoS One, 2016; 11: e0147604. 10 ANDERSON, GG, LAMDEN, MP, CIDLOWSKI, JA, et al. Comparative pulmonary surfactant-inducing effect of three corticosteroids in the near-term rat. Am J Obstet Gynecol, 1981; 139: 562-4.

11 ANTENATAL CORTICOSTEROID CLINICAL PRACTICE GUIDELINES PANEL. Antenatal corticosteroids given to women prior to birth to improve fetal, infant, child and adult health: Clinical Practice Guidelines. LIGGINS INSTITUTE (ed.). The University of Auckland 2015. 12 ASZTALOS, EV, MURPHY, KE, WILLAN, AR, et al. Multiple courses of antenatal corticosteroids for preterm birth study: outcomes in children at 5 years of age (MACS-5). JAMA Pediatr, 2013; 167: 1102-10.

13 AUER, RN. Hypoglycemic brain damage. Forensic Sci Int, 2004; 146: 105-10.

This article is protected by copyright. All rights reserved. 
14 BAER, RJ, ROGERS, EE, PARTRIDGE, JC, et al. Population-based risks of mortality and preterm morbidity by gestational age and birth weight. J Perinatol, 2016; 36: 1008-1013.

15 BALLARD, PL. Hormones and lung maturation. Monogr Endocrinol, 1986; 28: 1-354.

16 BALLARD, PL \& BALLARD, RA. Scientific basis and therapeutic regimens for use of antenatal glucocorticoids. Am J Obstet Gynecol, 1995; 173: 254-62.

17 BATTIN, MR, BEVAN, C \& HARDING, JE. Repeat doses of antenatal steroids and hypothalamic-pituitary-adrenal axis (HPA) function. Am J Obstet Gynecol, 2007; 197: 40.e16.

18 BECQUET, O, EL KHABBAZ, F, ALBERTI, C, et al. Insulin treatment of maternal diabetes mellitus and respiratory outcome in late-preterm and term singletons. BMJ Open, 2015; 5: e008192.

19 BERRY, LM, POLK, DH, IKEGAMI, M, et al. Preterm newborn lamb renal and cardiovascular responses after fetal or maternal antenatal betamethasone. Am J Physiol, 1997; 272: R1972-9.

20 BHUTTA, ZA, DAS, JK, BAHL, R, et al. Can available interventions end preventable deaths in mothers, newborn babies, and stillbirths, and at what cost? Lancet, 2014; 384: 347-70.

21 BOYLE, EM, JOHNSON, S, MANKTELOW, B, et al. Neonatal outcomes and delivery of care for infants born late preterm or moderately preterm: a prospective population-based study. Arch Dis Child Fetal Neonatal Ed, 2015; 100: F479-85.

22 BROWNFOOT, FC, GAGLIARDI, DI, BAIN, E, et al. Different corticosteroids and regimens for accelerating fetal lung maturation for women at risk of preterm birth. Cochrane Database Syst Rev, 2013: Cd006764.

23 CARLO, WA, MCDONALD, SA, FANAROFF, AA, et al. Association of antenatal corticosteroids with mortality and neurodevelopmental outcomes among infants born at 22 to 25 weeks' gestation. Jama, 2011; 306: 2348-58.

24 CARTWRIGHT, RD, HARDING, JE, CROWTHER, CA, et al. Repeat Antenatal Betamethasone and Cardiometabolic Outcomes. Pediatrics, 2018; 142.

$25 \mathrm{CHOI}, \mathrm{SJ}, \mathrm{SONG}, \mathrm{SE}, \mathrm{SEO}, \mathrm{ES}$, et al. The effect of single or multiple courses of antenatal corticosteroid therapy on neonatal respiratory distress syndrome in singleton versus twin pregnancies. Aust N Z J Obstet Gynaecol, 2009; 49: 173-9.

26 CLUVER, C, NOVIKOVA, N, KOOPMANS, CM, et al. Planned early delivery versus expectant management for hypertensive disorders from 34 weeks gestation to term. Cochrane Database Syst Rev, 2017; 1: Cd009273.

27 COLE, TJ, SHORT, KL \& HOOPER, SB. The science of steroids. Semin Fetal Neonatal Med, 2019; 24: 170-175.

28 CROWTHER, CA, DOYLE, LW, HASLAM, RR, et al. Outcomes at 2 years of age after repeat doses of antenatal corticosteroids. N Engl J Med, 2007; 357: 1179-89.

29 CROWTHER, CA \& HARDING, JE. Antenatal Glucocorticoids for Late Preterm Birth? N Engl J Med, 2016; 374: 1376-7.

This article is protected by copyright. All rights reserved. 
30 CROWTHER, CA, HARDING, JE, MIDDLETON, PF, et al. Australasian randomised trial to evaluate the role of maternal intramuscular dexamethasone versus betamethasone prior to preterm birth to increase survival free of childhood neurosensory disability (A*STEROID): study protocol. BMC Pregnancy Childbirth, 2013; 13: 104.

31 CROWTHER, CA, HASLAM, RR, HILLER, JE, et al. Neonatal respiratory distress syndrome after repeat exposure to antenatal corticosteroids: a randomised controlled trial. Lancet, 2006; 367: 1913-9.

32 CROWTHER, CA, MCKINLAY, CJ, MIDDLETON, P, et al. Repeat doses of prenatal corticosteroids for women at risk of preterm birth for improving neonatal health outcomes. Cochrane Database Syst Rev, 2015: Cd003935.

33 CROWTHER, CA, MIDDLETON, PF, VOYSEY, M, et al. Effects of repeat prenatal corticosteroids given to women at risk of preterm birth: An individual participant data metaanalysis. PLoS Med, 2019; 16: e1002771.

34 D'AMORE, A, AHLUWALIA, J, CHEEMA, I, et al. The effect of antenatal corticosteroids on fetal growth, survival, and neurodevelopmental outcome in triplet pregnancies. Am J Perinatol, 2004; 21: 1-8.

35 DALZIEL, SR, WALKER, NK, PARAG, V, et al. Cardiovascular risk factors after antenatal exposure to betamethasone: 30-year follow-up of a randomised controlled trial. Lancet, 2005; 365: 1856-62.

36 DE VECIANA, M. Diabetes ketoacidosis in pregnancy. Semin Perinatol, 2013; 37: 26773.

37 ELMEKKAWI, SF, MANSOUR, GM, ELSAFTY, MS, et al. Prediction of Fetal Hypertrophic Cardiomyopathy in Diabetic Pregnancies Compared with Postnatal Outcome. Clin Med Insights Womens Health, 2015; 8: 39-43.

38 FIGUERAS, F \& GRATACOS, E. An integrated approach to fetal growth restriction. Best Pract Res Clin Obstet Gynaecol, 2017; 38: 48-58.

39 GORDIJN, SJ, BEUNE, IM, THILAGANATHAN, B, et al. Consensus definition of fetal growth restriction: a Delphi procedure. Ultrasound in Obstetrics \& Gynecology, 2016; 48: 333-339.

40 GROOM, KM. Antenatal corticosteroids after 34weeks' gestation: Do we have the evidence? Semin Fetal Neonatal Med, 2019; 24: 189-196.

41 GUO, RX, YANG, LZ, LI, LX, et al. Diabetic ketoacidosis in pregnancy tends to occur at lower blood glucose levels: case-control study and a case report of euglycemic diabetic ketoacidosis in pregnancy. J Obstet Gynaecol Res, 2008; 34: 324-30.

42 GYAMFI-BANNERMAN, C, THOM, EA, BLACKWELL, SC, et al. Antenatal

Betamethasone for Women at Risk for Late Preterm Delivery. N Engl J Med, 2016; 374: 1311-20.

43 HAAS, DM, MCCULLOUGH, W, MCNAMARA, MF, et al. The first 48 hours: Comparing 12-hour and 24-hour betamethasone dosing when preterm deliveries occur rapidly. J Matern Fetal Neonatal Med, 2006; 19: 365-9.

This article is protected by copyright. All rights reserved. 
44 HANSEN, AK, WISBORG, K, ULDBJERG, $\mathrm{N}$, et al. Risk of respiratory morbidity in term infants delivered by elective caesarean section: cohort study. Bmj, 2008; 336: 85-7.

45 HOWIE, RN \& LIGGINS, GC. The New Zealand study of antepartum glucocorticoid treatment in lung development. In Biological and Clinical Perspectives Vol II, FARRELL, PM (ed.). Academic Press, 1982; 255-265.

46 JOBE, AH \& GOLDENBERG, RL. Antenatal corticosteroids: an assessment of anticipated benefits and potential risks. Am J Obstet Gynecol, 2018; 219: 62-74.

47 JOBE, AH, NITSOS, I, PILLOW, JJ, et al. Betamethasone dose and formulation for induced lung maturation in fetal sheep. Am J Obstet Gynecol, 2009; 201: 611.e1-7.

48 JOLLEY, JA, RAJAN, PV, PETERSEN, R, et al. Effect of antenatal betamethasone on blood glucose levels in women with and without diabetes. Diabetes Res Clin Pract, 2016; 118: 98-104.

49 KAEMPF, JW \& SURESH, G. Antenatal corticosteroids for the late preterm infant and agnotology. J Perinatol, 2017; 37: 1265-1267.

50 KAMATH-RAYNE, BD, ROZANCE, PJ, GOLDENBERG, RL, et al. Antenatal corticosteroids beyond 34 weeks gestation: What do we do now? Am J Obstet Gynecol, 2016; 215: 423-30.

51 KEMP, MW, NEWNHAM, JP, CHALLIS, JG, et al. The clinical use of corticosteroids in pregnancy. Hum Reprod Update, 2016; 22: 240-59.

$52 \mathrm{KEMP}, \mathrm{MW}, \mathrm{SCHMIDT}, \mathrm{AF} \& \mathrm{JOBE}, \mathrm{AH}$. Optimizing antenatal corticosteroid therapy. Semin Fetal Neonatal Med, 2019; 24: 176-181.

53 KERSTJENS, JM, BOCCA-TJEERTES, IF, DE WINTER, AF, et al. Neonatal morbidities and developmental delay in moderately preterm-born children. Pediatrics, 2012; 130: e265-72.

54 KERSTJENS, JM, DE WINTER, AF, BOCCA-TJEERTES, IF, et al. Risk of developmental delay increases exponentially as gestational age of preterm infants decreases: a cohort study at age 4 years. Dev Med Child Neurol, 2012; 54: 1096-101.

55 KHANDELWAL, M, CHANG, E, HANSEN, C, et al. Betamethasone dosing interval: 12 or 24 hours apart? A randomized, noninferiority open trial. Am J Obstet Gynecol, 2012; 206: 201.e1-11.

$56 \mathrm{KUK}, \mathrm{JY}, \mathrm{AN}, \mathrm{JJ}, \mathrm{CHA}, \mathrm{HH}$, et al. Optimal time interval between a single course of antenatal corticosteroids and delivery for reduction of respiratory distress syndrome in preterm twins. Am J Obstet Gynecol, 2013; 209: 256.e1-7.

57 LANGEN, ES, KUPERSTOCK, JL, SUNG, JF, et al. Maternal glucose response to betamethasone administration. Am J Perinatol, 2015; 30: 143-8.

58 LIGGINS, GC \& HOWIE, RN. A controlled trial of antepartum glucocorticoid treatment for prevention of the respiratory distress syndrome in premature infants. Pediatrics, 1972; 50: 515-25.

59 MACKIN, ST, NELSON, SM, KERSSENS, JJ, et al. Diabetes and pregnancy: national trends over a 15 year period. Diabetologia, 2018; 61: 1081-1088.

This article is protected by copyright. All rights reserved. 
60 MCEVOY, C, BOWLING, S, WILLIAMSON, K, et al. The effect of a single remote course versus weekly courses of antenatal corticosteroids on functional residual capacity in preterm infants: a randomized trial. Pediatrics, 2002; 110: 280-4.

61 MCGILLICK, EV, MORRISON, JL, MCMILLEN, IC, et al. Intrafetal glucose infusion alters glucocorticoid signaling and reduces surfactant protein mRNA expression in the lung of the late-gestation sheep fetus. Am J Physiol Regul Integr Comp Physiol, 2014; 307: R538-45. 62 MCKINLAY, CJ, CUTFIELD, WS, BATTIN, MR, et al. Cardiovascular risk factors in children after repeat doses of antenatal glucocorticoids: an RCT. Pediatrics, 2015; 135: e40515.

63 MCKINLAY, CJD, ALSWEILER, JM, ANSTICE, NS, et al. Association of Neonatal Glycemia With Neurodevelopmental Outcomes at 4.5 Years. JAMA Pediatr, 2017; 171: 972983.

64 MCKINLAY, CJD, CUTFIELD, WS, BATTIN, MR, et al. Mid-Childhood Bone Mass After Exposure to Repeat Doses of Antenatal Glucocorticoids: A Randomized Trial. Pediatrics, 2017; 139.

65 MELAMED, N, SHAH, J, YOON, EW, et al. The role of antenatal corticosteroids in twin pregnancies complicated by preterm birth. Am J Obstet Gynecol, 2016; 215: 482.e1-9.

66 MOORE, TR. A comparison of amniotic fluid fetal pulmonary phospholipids in normal and diabetic pregnancy. Am J Obstet Gynecol, 2002; 186: 641-50.

67 MORI, R, KUSUDA, S \& FUJIMURA, M. Antenatal corticosteroids promote survival of extremely preterm infants born at 22 to 23 weeks of gestation. J Pediatr, 2011; 159: 110114.e1.

68 MORRIS, JM, ALGERT, CS, FALSTER, MO, et al. Trends in planned early birth: a population-based study. Am J Obstet Gynecol, 2012; 207: 186.e1-8.

69 MOSES, RG, WONG, VC, LAMBERT, K, et al. The prevalence of hyperglycaemia in pregnancy in Australia. Aust N Z J Obstet Gynaecol, 2016; 56: 341-5.

70 MURPHY, KE, HANNAH, ME, WILLAN, AR, et al. Multiple courses of antenatal corticosteroids for preterm birth (MACS): a randomised controlled trial. Lancet, 2008; 372: 2143-51.

71 NADA, AM, SHAFEEK, MM, EL MARAGHY, MA, et al. Antenatal corticosteroid administration before elective caesarean section at term to prevent neonatal respiratory morbidity: a randomized controlled trial. Eur J Obstet Gynecol Reprod Biol, 2016; 199: 8891.

72 NATIONAL INSTITUTE FOR HEALTH AND CARE EXCELLENCE. NICE Guideline 25: Preterm labour and birth. The United Kingdom 2015.

$73 \mathrm{NOOH}, \mathrm{AM}, \mathrm{ABDELDAYEM}, \mathrm{HM}, \mathrm{ARAFA}, \mathrm{E}$, et al. Does implementing a regime of dexamethasone before planned cesarean section at term reduce admission with respiratory morbidity to neonatal intensive care unit? A randomized controlled trial. J Matern Fetal Neonatal Med, 2018; 31: 614-620.

This article is protected by copyright. All rights reserved. 

on the development of adult insulin sensitivity in a rat model. J Matern Fetal Neonatal Med, 2008; 21: 623-8.

76 ORTIZ, LA, QUAN, A, ZARZAR, F, et al. Prenatal dexamethasone programs hypertension and renal injury in the rat. Hypertension, 2003; 41: 328-34.

77 PATEL, RM. Short- and Long-Term Outcomes for Extremely Preterm Infants. Am J Perinatol, 2016; 33: 318-28.

78 PIPER, JM, XENAKIS, EM \& LANGER, O. Delayed appearance of pulmonary maturation markers is associated with poor glucose control in diabetic pregnancies. J Matern Fetal Med, 1998; 7: 148-53.

79 RADFORD, SK, DA SILVA COSTA, F, ARAUJO JUNIOR, E, et al. Clinical Application of Quantitative Foetal Fibronectin for the Prediction of Preterm Birth in Symptomatic Women. Gynecol Obstet Invest, 2018; 83: 285-289.

80 RAYBURN, WF, CHRISTENSEN, HD \& GONZALEZ, CL. A placebo-controlled comparison between betamethasone and dexamethasone for fetal maturation: differences in neurobehavioral development of mice offspring. Am J Obstet Gynecol, 1997; 176: 842-50; discussion 850-1.

81 ROBERTS, D, BROWN, J, MEDLEY, N, et al. Antenatal corticosteroids for accelerating fetal lung maturation for women at risk of preterm birth. Cochrane Database Syst Rev, 2017; 3: Cd004454.

82 ROSENBERG, RE, AHMED, AS, AHMED, S, et al. Determining gestational age in a lowresource setting: validity of last menstrual period. J Health Popul Nutr, 2009; 27: 332-8. 83 ROTTENSTREICH, A, LEVIN, G, KLEINSTERN, G, et al. Patterns of use and optimal timing of antenatal corticosteroids in twin compared with singleton pregnancies. Acta Obstet Gynecol Scand, 2018; 97: 1508-1514.

84 RYSAVY, MA, BELL, EF, IAMS, JD, et al. Discordance in Antenatal Corticosteroid Use and Resuscitation Following Extremely Preterm Birth. J Pediatr, 2019; 208: 156-162.e5. 85 RYSAVY, MA, LI, L, BELL, EF, et al. Between-hospital variation in treatment and outcomes in extremely preterm infants. N Engl J Med, 2015; 372: 1801-11.

86 SACCONE, G \& BERGHELLA, V. Antenatal corticosteroids for maturity of term or near term fetuses: systematic review and meta-analysis of randomized controlled trials. Bmj, 2016; 355: i5044.

87 SANYA, R, AL NAGGAR, E, GASIM, $M$, et al. Use or overuse of antenatal corticosteroids for suspected preterm birth. J Matern Fetal Neonatal Med, 2014; 27: 1454-6. 88 SCHIEVE, LA, TIAN, LH, RANKIN, K, et al. Population impact of preterm birth and low birth weight on developmental disabilities in US children. Ann Epidemiol, 2016; 26: 267-74.

This article is protected by copyright. All rights reserved. 
betamethasone-acetate for fetal lung maturation in preterm sheep. Am J Obstet Gynecol, 2018; 218: 132.e1-132.e9.

90 SCHMITZ, T, ALBERTI, C, URSINO, M, et al. Full versus half dose of antenatal betamethasone to prevent severe neonatal respiratory distress syndrome associated with preterm birth: study protocol for a randomised, multicenter, double blind, placebocontrolled, non-inferiority trial (BETADOSE). BMC Pregnancy Childbirth, 2019; 19: 67. 91 SENAT, MV, MINOUI, S, MULTON, O, et al. Effect of dexamethasone and betamethasone on fetal heart rate variability in preterm labour: a randomised study. $\mathrm{Br} \mathrm{J}$ Obstet Gynaecol, 1998; 105: 749-55.

92 SHARMA, A, DAVIS, A \& SHEKHAWAT, PS. Hypoglycemia in the preterm neonate: etiopathogenesis, diagnosis, management and long-term outcomes. Transl Pediatr, 2017; 6: 335-348.

93 SHEN, CL, ZHANG, Q, MEYER HUDSON, J, et al. Genetic Factors Contribute to Risk for Neonatal Respiratory Distress Syndrome among Moderately Preterm, Late Preterm, and Term Infants. J Pediatr, 2016; 172: 69-74.e2.

94 SIFIANOU, P, THANOU, V \& KARGA, H. Metabolic and hormonal effects of antenatal betamethasone after 35 weeks of gestation. J Pediatr Pharmacol Ther, 2015; 20: 138-43. 95 SKOLL, A, BOUTIN, A, BUJOLD, E, et al. No. 364-Antenatal Corticosteroid Therapy for Improving Neonatal Outcomes. J Obstet Gynaecol Can, 2018; 40: 1219-1239.

96 SMID, MC, STRINGER, EM \& STRINGER, JS. A Worldwide Epidemic: The Problem and Challenges of Preterm Birth in Low- and Middle-Income Countries. Am J Perinatol, 2016; 33: 276-89.

97 STUTCHFIELD, P, WHITAKER, R \& RUSSELL, I. Antenatal betamethasone and incidence of neonatal respiratory distress after elective caesarean section: pragmatic randomised trial. Bmj, 2005; 331: 662.

98 STUTCHFIELD, PR, WHITAKER, R, GLIDDON, AE, et al. Behavioural, educational and respiratory outcomes of antenatal betamethasone for term caesarean section (ASTECS trial). Arch Dis Child Fetal Neonatal Ed, 2013; 98: F195-200.

99 SUBTIL, D, TIBERGHIEN, P, DEVOS, P, et al. Immediate and delayed effects of antenatal corticosteroids on fetal heart rate: a randomized trial that compares betamethasone acetate and phosphate, betamethasone phosphate, and dexamethasone. Am J Obstet Gynecol, 2003; 188: 524-31.

100 TITA, AT, LANDON, MB, SPONG, CY, et al. Timing of elective repeat cesarean delivery at term and neonatal outcomes. N Engl J Med, 2009; 360: 111-20.

101 UNO, H, EISELE, S, SAKAI, A, et al. Neurotoxicity of glucocorticoids in the primate brain. Horm Behav, 1994; 28: 336-48.

102 VIGNOLES, P, GIRE, C, MANCINI, J, et al. Gestational diabetes: a strong independent risk factor for severe neonatal respiratory failure after 34 weeks. Arch Gynecol Obstet, 2011; 284: 1099-104.

This article is protected by copyright. All rights reserved. 
103 VITERI, OA, BLACKWELL, SC, CHAUHAN, SP, et al. Antenatal Corticosteroids for the Prevention of Respiratory Distress Syndrome in Premature Twins. Obstet Gynecol, 2016; 128: 583-91.

104 VITERI, OA, DINIS, J, ROMAN, T, et al. Timing of Medically Indicated Delivery in Diabetic Pregnancies: A Perspective on Current Evidence-Based Recommendations. Am J Perinatol, 2016; 33: 821-5.

105 VOGEL, JP, OLADAPO, OT, PILEGGI-CASTRO, C, et al. Antenatal corticosteroids for women at risk of imminent preterm birth in low-resource countries: the case for equipoise and the need for efficacy trials. BMJ Glob Health, 2017; 2: e000398.

106 WAPNER, RJ, SOROKIN, Y, MELE, L, et al. Long-term outcomes after repeat doses of antenatal corticosteroids. N Engl J Med, 2007; 357: 1190-8.

107 WAPNER, RJ, SOROKIN, Y, THOM, EA, et al. Single versus weekly courses of antenatal corticosteroids: evaluation of safety and efficacy. Am J Obstet Gynecol, 2006; 195: 633-42. 108 WEINSTEIN, JR, THOMPSON, LM, DIAZ ARTIGA, A, et al. Determining gestational age and preterm birth in rural Guatemala: A comparison of methods. PLoS One, 2018; 13: e0193666.

109 WHO REPRODUCTIVE HEALTH LIBRARY. WHO recommendation on antenatal corticosteroid therapy in women with preterm prelabour rupture of membranes. World Health Organization: Geneva, November 2015.

110 WYRWOLL, CS, HOLMES, MC \& SECKL, JR. 11beta-hydroxysteroid dehydrogenases and the brain: from zero to hero, a decade of progress. Front Neuroendocrinol, 2011; 32: 265-86.

111 ZANARDO, V, SIMBI, AK, FRANZOI, $\mathrm{M}$, et al. Neonatal respiratory morbidity risk and mode of delivery at term: influence of timing of elective caesarean delivery. Acta Paediatr, 2004; 93: 643-7.

This article is protected by copyright. All rights reserved. 


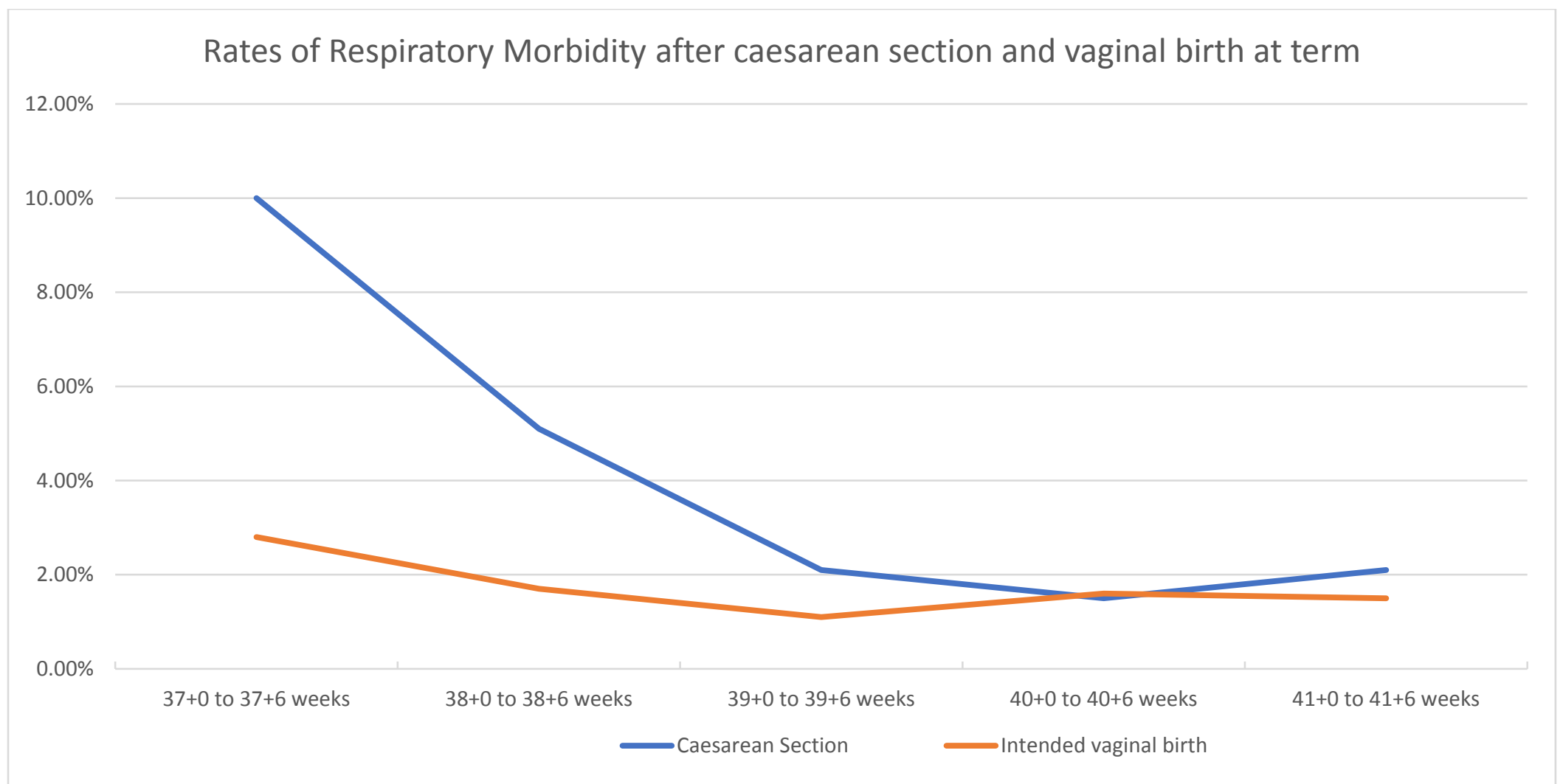

Figure 1: Increased rate of respiratory morbidity after caesarean section compared to intended vaginal birth (data adapted from Hansen AK et al). ${ }^{1}$

This article is protected by copyright. All rights reserved. 


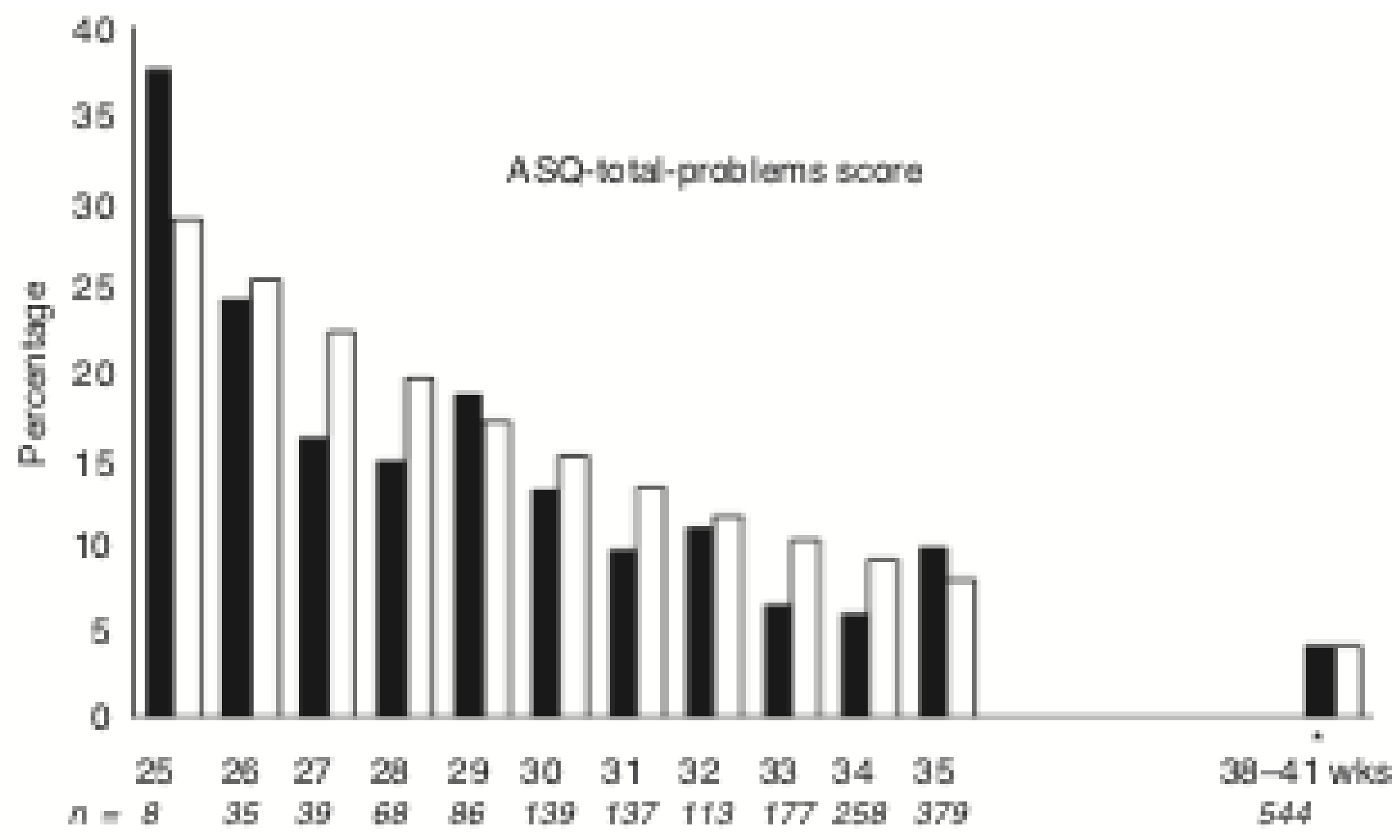

Figure 2: Decreasing proportion of neurodevelopmental disability with increasing gestational age (data reproduced from Kerstjens JM et al). ${ }^{71}$ 
Table 1: Key recommendations regarding antenatal corticosteroid administration by international guidelines 


\begin{tabular}{|c|c|c|c|c|c|}
\hline Guideline & $\begin{array}{l}\text { Recommendations } \\
\text { regarding gestation } \\
\text { for routine } \\
\text { administration prior } \\
\text { to preterm birth }\end{array}$ & $\begin{array}{c}\text { Recommendations } \\
\text { regarding } \\
\text { administration prior } \\
\text { to } 24+0 \text { weeks } \\
\text { gestation } \\
\end{array}$ & $\begin{array}{l}\text { Recommendations } \\
\text { regarding } \\
\text { administration after } \\
34+0 \text { weeks }\end{array}$ & $\begin{array}{l}\text { Recommendations } \\
\text { regarding } \\
\text { administration of } \\
\text { repeat doses }\end{array}$ & $\begin{array}{c}\text { Recommendations } \\
\text { regarding } \\
\text { administration prior } \\
\text { to elective caesarean } \\
\text { section } \\
\end{array}$ \\
\hline $\begin{array}{l}\text { ACOG Committee } \\
\text { Opinion No } 7132017^{2}\end{array}$ & $\begin{array}{l}\text { Single course when } \\
\text { there is a risk of } \\
\text { preterm delivery } \\
\text { within the next } 7 \\
\text { days } \\
24^{+0} \text { to } 33^{+6} \text { weeks }\end{array}$ & $\begin{array}{l}\text { Individualise } \\
\text { depending on the } \\
\text { family's decision } \\
\text { regarding } \\
\text { resuscitation } \\
\text { - From } 23^{+0} \text { weeks }\end{array}$ & $\begin{array}{l}\text { A single course } \\
\text { when there is a risk } \\
\text { of preterm delivery } \\
\text { between } 34^{+0} \text { and } \\
36^{+6} \\
\text { Only for women } \\
\text { who have not } \\
\text { already received a } \\
\text { course of } \\
\text { corticosteroids }\end{array}$ & $\begin{array}{l}\text { - } \quad \text { No more than } 2 \\
\text { courses } \\
\text { - Only up to } 34^{+0} \\
\text { weeks' gestation } \\
\text { - Only if previous } \\
\text { course was more } \\
\text { than } 14 \text { days prior } \\
\text { A "rescue dose" } \\
\text { can be given } 7 \\
\text { days after the prior } \\
\text { course }\end{array}$ & $\begin{array}{ll} & \text { No } \\
& \text { recommendations }\end{array}$ \\
\hline $\begin{array}{l}\text { NICE Guideline (NG25) } \\
\text { Preterm Labour and } \\
\text { Birth } 2015^{3}\end{array}$ & $\begin{array}{l}\text { - } 24+0 \text { to } 33+6 \\
\text { weeks }\end{array}$ & $\begin{array}{l}\text { Individualise } \\
\text { according to } \\
\text { circumstances } \\
\text { between } 23+0 \text { and } \\
23+6 \text { weeks }\end{array}$ & $\begin{array}{l}\text { - Consider between } \\
34+0 \text { and } 35+6 \\
\text { weeks }\end{array}$ & $\begin{array}{l}\text { Do not routinely } \\
\text { offer repeat } \\
\text { courses but if } \\
\text { recommending } \\
\text { consider interval } \\
\text { between last dose, } \\
\text { gestational age and } \\
\text { likelihood of birth in } \\
\text { next } 48 \text { hours }\end{array}$ & $\begin{array}{ll}\text { - } & \text { No } \\
& \text { recommendations }\end{array}$ \\
\hline $\begin{array}{l}\text { New Zealand and } \\
\text { Australian Clinical } \\
\text { Practice Guidelines } \\
2015^{4}\end{array}$ & $\begin{array}{l}\text { Gestation less than } \\
34+6 \text { weeks where } \\
\text { birth is expected } \\
\text { within } 7 \text { days (even } \\
\text { if expected within } \\
24 \text { hours) }\end{array}$ & $\begin{array}{ll}- & \text { No specific } \\
\text { recommendation } \\
\text { but no lower limit of } \\
\text { gestation given in } \\
\text { main } \\
\text { recommendations }\end{array}$ & $\begin{array}{l}\text { - General } \\
\text { recommendation is } \\
\text { administration up to } \\
34+6 \text { weeks } \\
\text { No specific } \\
\text { recommendations } \\
\text { beyond } 34+6 \\
\text { weeks apart from } \\
\text { prior to elective } \\
\text { caesarean }\end{array}$ & $\begin{array}{l}\text { Gestation less than } \\
\text { 32+6 weeks where } \\
\text { birth is expected } \\
\text { within } 7 \text { days } \\
\text { At least } 7 \text { days } \\
\text { after a previous } \\
\text { course of } \\
\text { corticosteroids }\end{array}$ & $\begin{array}{l}\text { - After } 34+6 \text { weeks if } \\
\text { there is known fetal } \\
\text { lung immaturity }\end{array}$ \\
\hline $\begin{array}{l}\text { No. 364-Antenatal } \\
\text { Corticosteroid Therapy } \\
\text { for Improving Neonatal }\end{array}$ & $\begin{array}{l}\text { Gestation between } \\
24+0 \text { and } 34+6 \\
\text { weeks when }\end{array}$ & $\begin{array}{l}\text { Women at risk of } \\
\text { delivery between } \\
22+0 \text { to } 23+6\end{array}$ & $\begin{array}{l}\text { Consider between } \\
35+0 \text { and } 36+6 \\
\text { weeks in select }\end{array}$ & $\begin{array}{l}\text { Routine use of } \\
\text { rescue or repeat }\end{array}$ & $\begin{array}{l}\text { Routine use is not } \\
\text { recommended prior } \\
\text { to pre-labour }\end{array}$ \\
\hline
\end{tabular}

This article is protected by copyright. All rights reserved. 


\begin{tabular}{|c|c|c|c|c|c|}
\hline $\begin{array}{l}\text { Outcomes Canada } \\
2018^{5}\end{array}$ & $\begin{array}{l}\text { delivery is } \\
\text { expected within } 7 \\
\text { days. }\end{array}$ & $\begin{array}{l}\text { weeks when } \\
\text { delivery is } \\
\text { expected within } 7 \\
\text { days and intensive } \\
\text { care is planned for } \\
\text { the baby. }\end{array}$ & $\begin{array}{l}\text { clinical situations } \\
\text { after risks and } \\
\text { benefits are } \\
\text { discussed with the } \\
\text { woman and the } \\
\text { paediatric care } \\
\text { provider(s) }\end{array}$ & $\begin{array}{l}\text { courses is not } \\
\text { recommended } \\
\text { A single rescue } \\
\text { course of antenatal } \\
\text { corticosteroid } \\
\text { therapy may be } \\
\text { administered after } \\
\text { risks and benefits } \\
\text { are discussed with } \\
\text { the woman }\end{array}$ & $\begin{array}{l}\text { Caesarean section } \\
\text { at term }\end{array}$ \\
\hline
\end{tabular}

1. Hansen AK, Wisborg K, Uldbjerg N, Henriksen TB. Risk of respiratory morbidity in term infants delivered by elective caesarean section: cohort study. Bmj. 2008;336(7635):85-87.

2. Committee Opinion No. 713: Antenatal Corticosteroid Therapy for Fetal Maturation. Obstet Gynecol. 2017;130(2):e102-e109.

3. National Institute for Health and Care Excellence. NICE Guideline 25: Preterm labour and birth. The United Kingdom 2015.

4. Antenatal Corticosteroid Clinical Practice Guidelines Panel. Antenatal corticosteroids given to women prior to birth to improve fetal, infant, child and adult health: Clinical Practice Guidelines. The University of Auckland 2015.

5. Skoll A, Boutin A, Bujold E, et al. No. 364-Antenatal Corticosteroid Therapy for Improving Neonatal Outcomes. J Obstet Gynaecol Can. 2018;40(9):1219-1239.

This article is protected by copyright. All rights reserved. 


\section{University Library}

\section{- M M I E E R VA A gateway to Melbourne's research publications}

Minerva Access is the Institutional Repository of The University of Melbourne

Author/s:

Thevathasan, I;Said, JM

Title:

Controversies in antenatal corticosteroid treatment

Date:

2020-03-10

Citation:

Thevathasan, I. \& Said, J. M. (2020). Controversies in antenatal corticosteroid treatment.

PRENATAL DIAGNOSIS, 40 (9), pp.1138-1149. https://doi.org/10.1002/pd.5664.

Persistent Link:

http://hdl.handle.net/11343/275529 